\title{
Soviet Standardized Single-Family House: the Failed Hope of Non-Communal Living in Postwar Lithuanian Towns
}

\author{
Aistė Galaunytė, Vilnius Gediminas Technical University
}

\begin{abstract}
The article is on the issue of standardized single-family houses introduced by the Soviet government in post-war Lithuania, which later were strictly prohibited. The relation between standardization and communist ideology and the Soviet law is analysed. The author argues that despite the significant influence of the Soviet law, standardized houses were symbols of welfare, modernist architecture and modern living. The lack and absence of them had a negative impact on the architecture of standardized houses in contemporary Lithuania.
\end{abstract}

Keywords - Single-family house, standardized architectural design, modernist architecture, soviet architecture, modernization, cold war.

\section{INTRODUCTION}

After World War II, one of the principal tasks of the soviet building and construction sector, was to implement mass industrialization, followed by standardization. That was a reasonable aim, familiar to all post-war countries, as many of housing estates were destroyed during the war. Eventually, architects could experiment with innovative technologies and new ways of constructing various houses: apartment blocks, semi-detached houses, single-family houses. Only, in the Soviet Union one did not have much choice what to create, where and how to live. Alongside with Nikita Khrushchev's promise of 1957 to "provide a flat for every family" and the whole communist ideology praising public ownership and communal control, the grounds for mass housing projects and their implementation were set up. In this case, designing standardized single-family houses, especially in big towns, seemed like an anti-thesis to the whole system. Nevertheless, for a period of time, standardized single-family houses were designed and built in towns of Lithuania (then a part of Soviet Union). Were they symbols of freedom and welfare or just another way to embody communist doctrine? Can we recognize the traits of modernity in this architecture? How they (or their absence) formed the architecture of a typical single-family house in contemporary Lithuania? The research aims to answer these questions, as well as to present and investigate this often disregarded typological group of soviet architecture.

It is important to stress that in this case the phrase "standardized single family house" defines the houses of prefabricated elements as well as "traditional" houses of brick and wood, but both of standardized architectural designs.

Various investigation methods were used to provide and analyse the data for this paper. Those include studies of law and regulations of the Soviet Union's, analysis of soviet press releases and architecture catalogues, qualitative analysis of soviet standardized single-family houses comparing them with Western ones.

\section{Soviet Standardized Single-Family House: Hostage of Communist Ideology}

"We shape our dwellings and afterwards our dwellings shape us" - this quote of Winston Churchill [1] could be re-phrased to fit the definition of a soviet house. The word "We" should be replaced by "They". Being a part of the Soviet Union Lithuania embraced the mode of living, rarely encountered before - i.e. standardized dwellings. Maybe it was the result of post-war times in general, but soviet citizens, unlike their counterparts in the West, could not freely choose in what kind of house or flat to live.

All innovations, as well as the methods and means for standardization of soviet architecture could be implemented without much of disruption in a state like Soviet Union. This was because "the construction industry in the Soviet Union was centrally organized. All authorities and political decision makers were subject to instructions issued by the Central Committee" [2]. Standardized single-family houses in Soviet Lithuanian towns were designed by "Miestprojektas" - Design Institute for Town Construction in Vilnius, "Žemprojektas" - Design Institute for Agricultural Construction in Kaunas, and by production groups under Architects' Boards of towns (Lith. Gamybinès grupés prie miesto architektu valdybos) in smaller towns [3]. Designing commissions always came from "Gosstroi" - the State Committee for Construction in Moscow, which was a subordinate of Central Committee.

Similar schemes applied not only to executing standardized designs, but also to "individual" designs of architecture as well. So standardization of architectural designs was like a "double-check" for the totalitarian state to make sure that the living environment is strictly monitored. Meaning, that not only regular design process and results were controlled, but, in case of standardization, large, prefabricated modules were used, which reduced variability, promoting only certain types of design and the "best", state commissioned and supported designs could be copied indefinitely. Of course, the exposed official reasons for standardization were only economical: "The main challenge and aim for the builders brought up during the 21st and 22nd Congress of the Communist Party and Plenum of Central Committee in 1959, was the industrialization. $<\ldots>$ Pre-fabricated details and construction elements must be used as often as possible. 


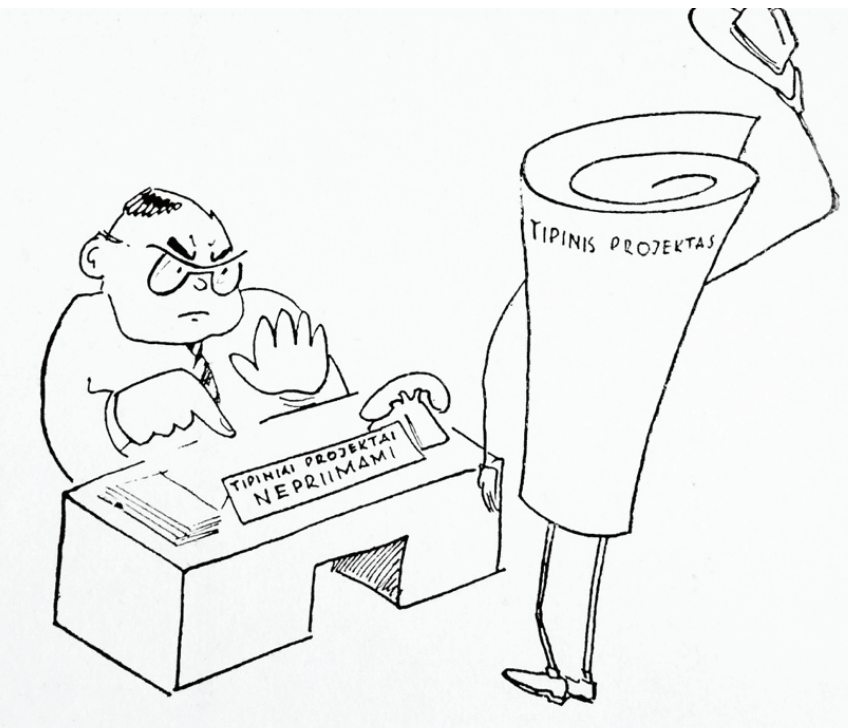

Fig. 1. Disease of individuality, caricature of 1962 [19].

This would make the construction process cheaper and faster. The aim is to have the pre-fabricated element as big as possible. $<\ldots>$ It is important that the same elements would be repeatedly used in various buildings." [4]. Such definitions instantly suggest monotonous repetitiveness, lack of context, lack of flexibility, lack of freedom. But, the need for standardization, once put as a priority, could not be questioned in a totalitarian state. Even more - standardization and industrialization were often among the principal topics in architectural press, and the headlines were full of propaganda: "Large-panel building construction should be exemplary" [5]; "Industrialization is the basis of construction in contemporary Lithuania" [6]. On the contrary - creation of buildings of so called "individual designs" was often criticized and ridiculed, like in the cartoon of 1962 (Fig. 1).

Analysing the given circumstances, soviet standardized single-family house was standing in an ambiguous position, representing, on the one hand, the freedom of non-communal living, but on the other hand - the strict and closed system of soviet standardized design.

This unconventional situation of standardized single-family house could not pass unnoticed. During the years when Lithuania was a part of the Soviet Union, there was only one type of buildings, which, for a period of time was prohibited - a single-family house. This radical move (prohibition) suggests that a single-family house was regarded as a threat or somewhat unsuitable way of living for a soviet citizen. The prohibition was not related to the house being of "an individual design" or "standardized design" though the "individual" type was constantly criticized - it just banned the whole group. Actually, the standardized single-family houses received even tougher restrictions. The original text of the decree No. 592 issued on 10 September 1962, states the following: "It is prohibited to build individual houses in Vilnius and Kaunas...”. Later, on 15 December, decree No. 186 states: "It is prohibited to built any type of standardized single-family houses in all Lithuanian towns and town type settlements..." [7]. This fact is very important, because, as it was explained above, standardized designs were state supported and created so they could be repeated many, many times. "Individual designs" could not compete with their quantity. Therefore, banning single-family houses of standardized designs in all towns obviously meant a drastic reduction in the development of single-family houses in general.

It is peculiar that before the initial ban in 1962, this type of housing was celebrated and even regarded as equal to apartment blocks. For instance, in 1958, Lithuanian Central Committee of the Communist Party declared that until 1960, $2000000 \mathrm{~m}^{2}$ of dwelling space will be build; $800000 \mathrm{~m}^{2}$ (almost half) of them should have been single-family houses [8]. This typological group was praised as having better living conditions, it was said that there are not enough of these houses in Lithuania (in comparison to Scandinavia or even the United States of America!) [9]. Standardized designs of houses was, of course, a priority: "Today, almost all houses are constructed according to the standardized projects," [4] wrote K. Jakovlevas in 1961. The designs of standardized single-family houses were published in catalogues issued by Design Institutes or in extended brochures dedicated to one project. These brochures were handed out for free, 5000 copies of one project could be printed. As in any other typology, projects were clustered in series. Every project had an identification number (in the Soviet Union this applied to standardized buildings of all typologies). For example, project number I-59-3: I-59 identifies the series and 3 is the project sequence number in the series, which means that there should be projects I-59-1 and I-59-2.

The legal existence of single-family houses started to change in 1962, when it was prohibited to construct them in major Lithuanian towns - Vilnius and Kaunas, as well as in principal seaside resort Palanga. Prohibitions to construct in Klaipeda (the main port town), Druskininkai, Neringa, Birštonas (popular resort towns) followed in 1975. One could trace a correlation between the diminishing construction of soviet single-family houses in the 60s and the American National Exhibition held in Moscow in 1959. A full scale American model house "Splitnik" was displayed at the exhibition, where the U.S.A. president Richard Nixon "proclaimed that $\langle\ldots\rangle$ suburban home represented nothing less than American freedom" [10]. For a short time "Splitnik" served as a reference (Fig. 2) to soviet architects. Though later the Soviet Union switched their focus to mass construction of apartment blocks, probably knowing that they could not compete with Americans in the field of construction of single-family houses.

\section{Blur red Traits of Modernity in Soviet Standardized Single-Family Houses}

Modernization, by definition, is "the transformation from traditional, rural, agrarian society to secular, urban, industrial society" [11]. Following that, Lithuania really got through the process of modernization while being incorporated in the Soviet Union. Religion was excluded from public life, citizens were pushed to towns, or at least to urbanized village communities (collective 


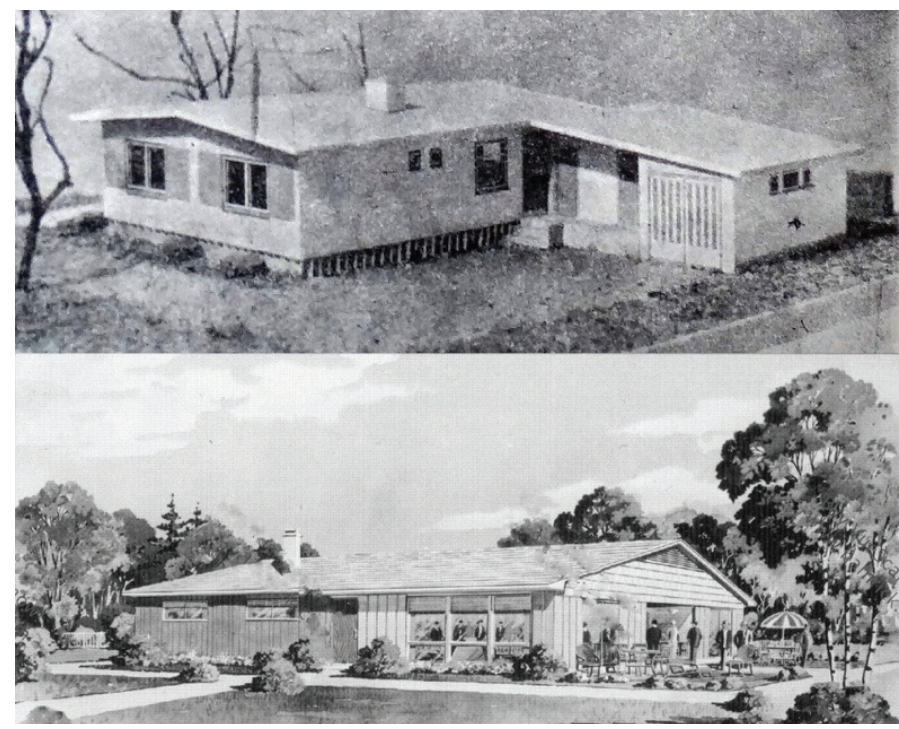

Fig. 2. Soviet experimental single-family house in 1961 (above) [20] and American "Splitnik" [21].

farms) from their farmsteads, and industrialization, as explained earlier, was a priority. But modernization was not always a synonym for modern architecture. During the period of this investigation, starting with the end of World War II till 1962, the Soviet Union was ruled by Stalin (1922-1952) and N. Khrushchev (1953-1964). Stalin's aesthetical preferences were far from modernist, nevertheless the following paragraph argues that standardized single-family houses of those times could be considered modern. The period from 1945 to 1962 and on-wards, could be divided into two stages in relation to modernization. The first stage, which correlates with Stalin's rule and the style of social realism, represents modernization through technology and engineering. The second stage, which correlates with Khrushchev's rule and the beginning of soviet modernism, represents modernization through technology and engineering as well as through pure, modernistic architectural forms.

After the war soviet standardized single-family house created a chance (at least theoretically) for every family to live in a house with sewerage, running water and other features of a modern house. At those times, the fact of having running water at home seemed more relevant than the aesthetic of a house. For example, the front page of the brochure of project I-59-4 (Fig. 3), issued in 1959, states: “... with water supply and sewerage" [12], showing that these amenities were rare, and therefore appreciated. These, now looking minor, accomplishments were used as propaganda against pre-war living conditions of working class or lower middle class families: " $<\ldots>$ the huts of peasants were designated to stand in the worst parcels, in wet, swampy and unhealthy places" [13]. This propaganda was not completely false. Pre-war modernist houses, constructed from bricks, were meant mostly for the upper class families, the others lived in the wooden ones (not counting wooden holiday villas). Soviets were quick to prohibit the construction of wooden houses in towns [9, 230], replacing

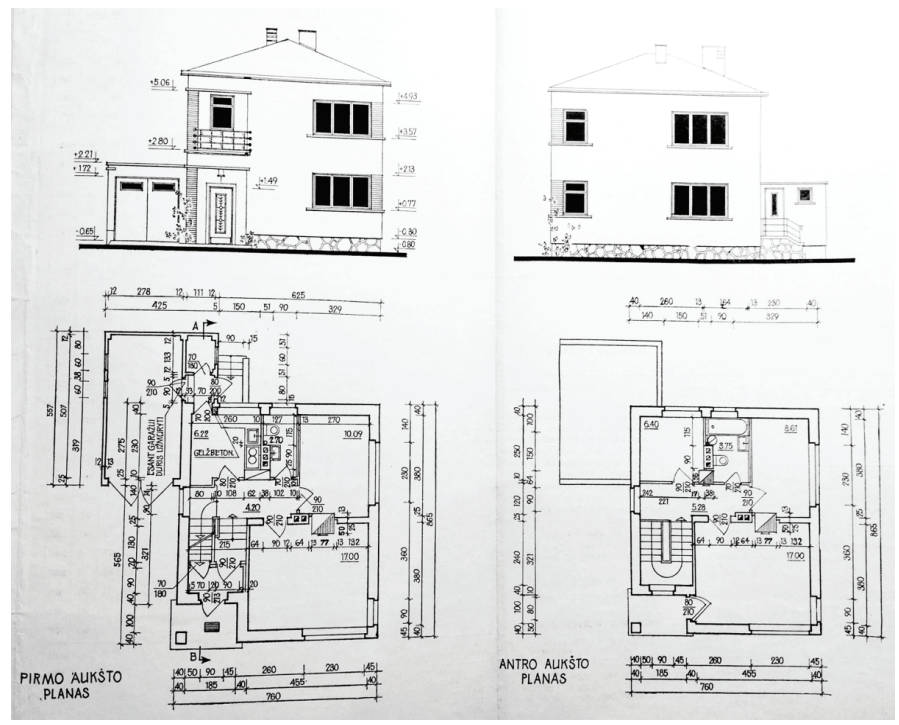

Fig. 3. Plans and elevations of project I-59 [22].

them with brick or large panel houses. New standardized houses were a mixture of Russian and German traditional architecture combined with stylized Lithuanian traditional elements and even interwar modernism.

They represented a peculiar hybrid of modernity and communist ideology, constructed using at that time innovative technologies, with garages; but at the same time with "folk" architecture symbols, pitched roofs, no separate bedrooms for children, etc. In 1955, "folk" symbols and ornaments started to disappear from architectural designs as well as from standardized single-family houses after the famous decree No. 1871 "On Elimination of Excesses in Design and Construction". Therefore, since the end of the 50s, traits of modern architecture could be seen in the designs of standardized single-family houses. At that time, one storey houses with flat roofs started to be designed - the type of a house so familiar to modernist tradition. Lithuanian architect Feliksas Bielinskis (1904-1986) created some peculiar, American looking, experimental designs for single-family houses (Fig. 5).

Bielinskis was a prominent interwar period architect, creator of highly celebrated modernist buildings in independent Lithuania. During the Soviet occupation, he was working at the Institute for architecture and construction in Kaunas, where he designed experimental and standardized houses (together with colleagues architects V. Raginis, S. Sederevičius, K. Beržanskis, V. Bulkevičius, S. Stanevičius). The article published in the most important magazine for architecture professionals of that time "Statyba ir architektūra" reflects only economic and construction "values" of houses of concrete slabs or reinforced cement structure: " $<\ldots$.. $>$ they will be cheaper than brick houses", "they could be constructed during 4-5 shifts", "very cheap houses" [14]. Architectural forms and value of the houses were not mentioned, though some of them bear a significance to Case Study Houses a post-war housing program (1945-1966) initiated in California, 

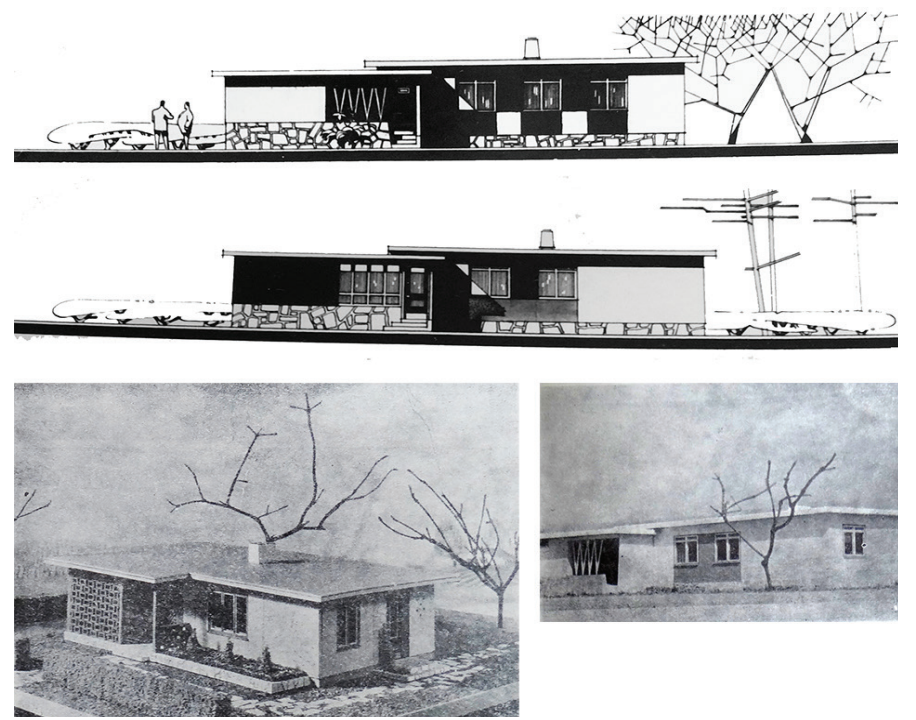

Fig. 4. Experimental single-family houses designed by F. Bielinskis [23].

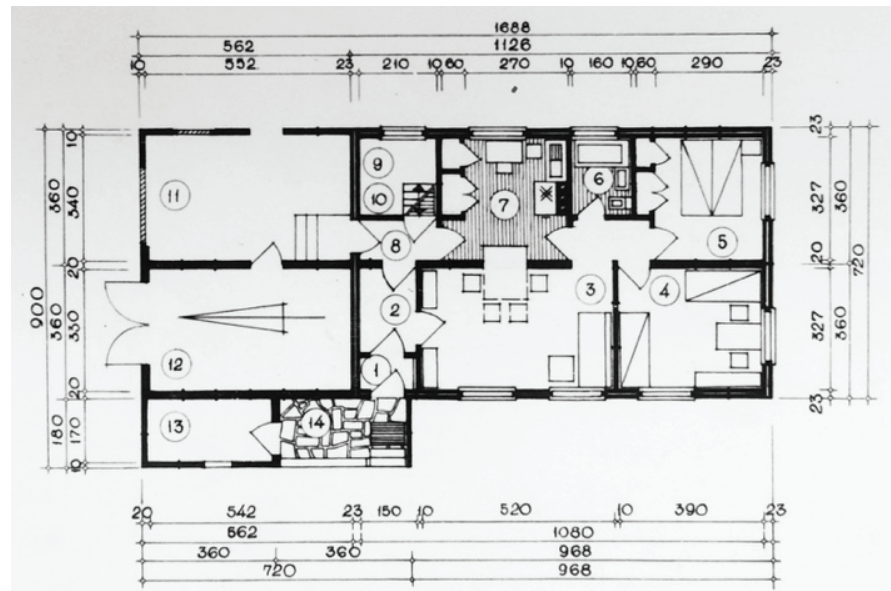

Fig. 6. Plan of a single-family house designed by Bielinskis and Raginis, 1960 [25].

U.S.A. [15]. Bielinskis' designs have similar roof; he also uses pergolas; decorative stones are exposed at the exterior (Fig. 6). One could also find similarities between Bielinskis' houses and Courtyard houses in Tapiola, Finland (architect Pentti Ahola, 1961) as well as various other Finish examples (Fig. 6), (Fig. 7). Unfortunately, none of Bielinskis' house designs were ever implemented, though one experimental house was supposed to be built as part of the quarter at Umėdžių street, Vilnius.

The most successful designs of standardized single-family houses could be borrowed and build in all republics of the same climatic region of the Soviet Union. For example, Lithuania belonged to the 2nd and 3rd climatic region, as well as Latvia, Estonia, Moldavia, Ukraine, Belorussia and part of Kazakhstan [16]. One could really find cultural similarities between the Baltic states, but buildings with the same kind of architecture in Lithuania and Kazakhstan was a total ignorance of the context. On

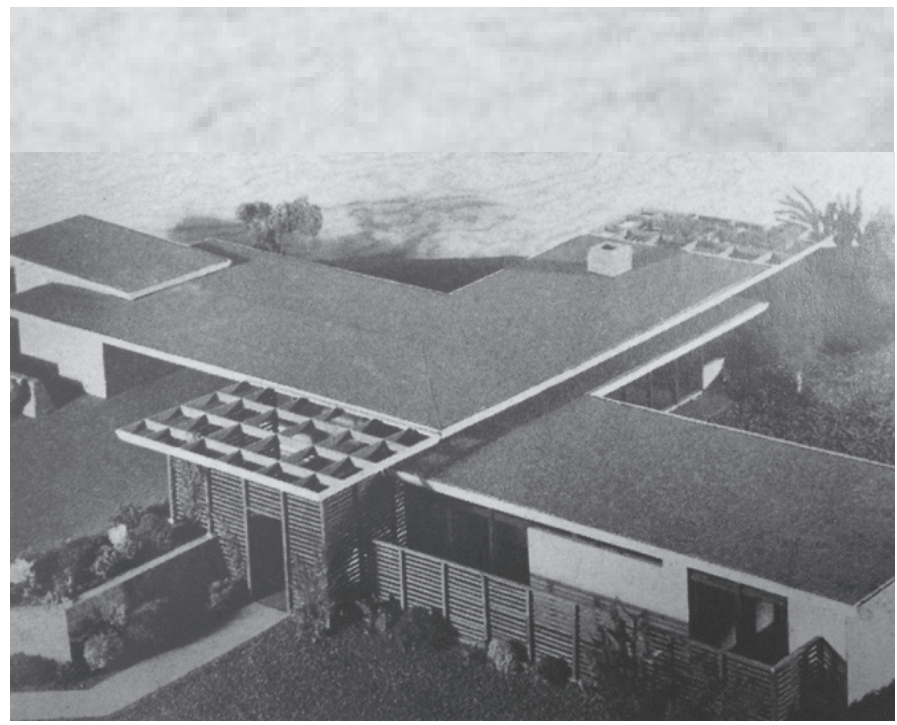

Fig. 5. Case study house No. 12 [24]

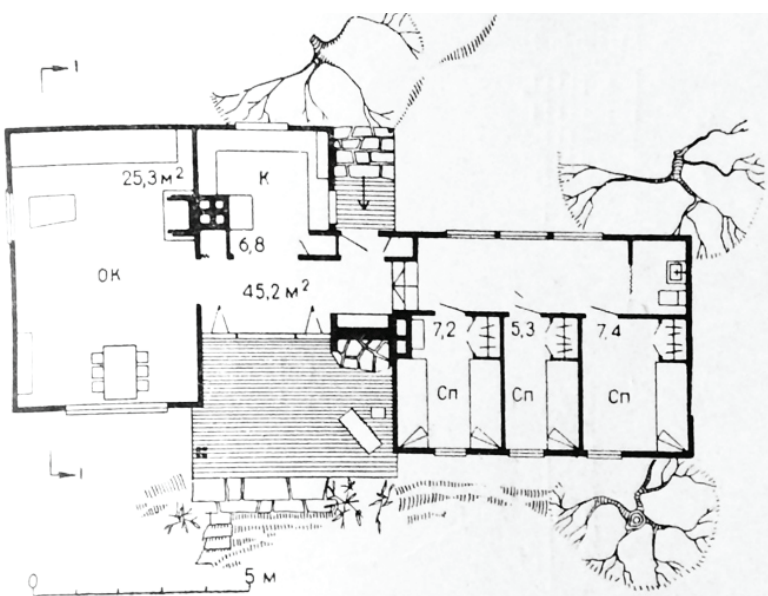

Fig. 7. Plan of a Finish house in 1960s [26].

the other hand, unified designs, negation of historical forms and ornaments, sometimes even negation of the [historical] context (i.e. Le Corbusier Plan Voisin) - were embraced by the Modern Movement/International Style. Designs similar to Bielinskis' designs of houses could be found in the "Gosstroi" catalogue of 1969, only they were applied to houses with more than one flat (Fig. 8). In Lithuania this "pavilion" type architecture was later used in public buildings like Summer Library in Palanga, Flower Pavilion in Vilnius, the project of pre-fabricated holiday pavilion for 14 people (which received the All Union prize), etc.

\section{Outcome of Non-Existing Tradition}

The regulations for the construction of single-family houses in Lithuania became more liberal by the end of the $80 \mathrm{~s}$, resulting in post-modernist chaos. After the restoration of 


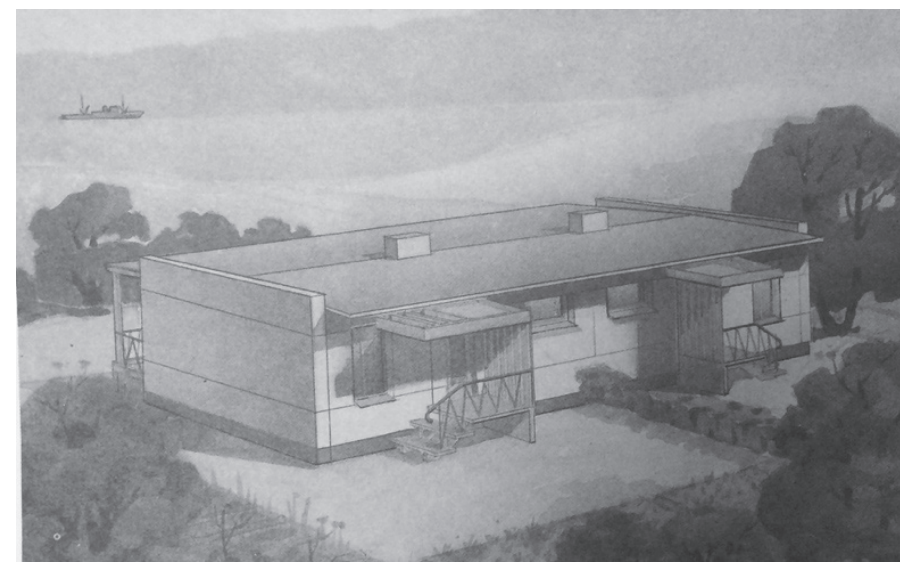

Fig. 8. Semi-detached house project 181-53-46 CП, from the "Gosstroi" catalogue [27].

Independence in 1990, single-family and low rise residential housing was set as a priority. It was then, that the Minister of Construction and Urban Development architect Algimantas Nasvytis stated: "Massive apartment buildings, nowadays occupying so much of the town area, have no future. Our landscape is more suitable for houses and villas than for tower-blocks." The strategy was the following: "Residential buildings should be made private property, their designed area and height have to be much smaller" [17]. However, despite the Minister's statement that "our landscape is more suitable for houses and villas", the architectural tradition of single-family house (one should not mix up urban residential house with farmstead, the concept of which has always been different), was a bit forgotten. Perhaps it has never been deeply rooted either, since having a brick house in a city was only available to a minority of elite class. F. Bielinskis' houses of the 60 s were vaguely known and never became a design reference, probably because they were never built. Twenty years later, Nasvytis' expectations did not come true. According to the latest data of "Statistics Lithuania", in 2011, there were almost twice as many flats in the apartment building than single-family houses (respectively there were 836796 flats, 496963 houses, and 55 043 semi-detached houses in Lithuania) [18]. Where, given this diverse situation, do standardized single-family houses stand? Or are there any? After the collapse of the Soviet Union, Design Institutes split into various private architectural practices. Most of factories, like Alytus ENSK (Alytus Factory for Experimental Housing Construction), which had produced prefabricated construction elements, were shut down. Large, prefabricated modules became a rarity in the construction of single-family houses (and in multi-storey apartment buildings as well). Nevertheless, the popularity of catalogues, printed and online, representing standardized single-family houses significantly increased. The increase could be due to the much cheaper price of standardized design (around 1000 euros per design project in Vilnius, whereas the price of the project of a unique design could start from 2500 euros and more). The quality of architectural design and lack of complex urban planning remains the main problem, as standardized designs is often an infusion of American and Pol- ish suburban architecture scattered disorderly at the outskirts of Lithuanian cities.

\section{Conclusion}

Soviet standardized single-family houses for towns have a rather short history in Soviet Lithuania. Single-family house was the only typological group in the Soviet Union which for some time was prohibited. Trying to answer the question why this happened, one can think of several reasons. First, there was a great shortage of living space in Soviet Lithuanian towns after the war. The fastest and cheapest way to diminish the shortage was the construction of multi-storey apartment blocks (not single-family houses). Secondly, the radical move of prohibition suggests that single-family houses were regarded as a threat or somewhat unsuitable way of living for soviet citizens. Thirdly, even if there was a chance to build a single-family house, lack of building materials and difficulties in acquiring a parcel resulted in very few constructions of single-family houses in the towns of Soviet Lithuania.

Soviet standardized single-family houses designed in Lithuania up until 1962, though a mass product of a totalitarian state, served as symbols of people's welfare throughout all soviet period, as the majority of the population lived in modest flats. Right after the war, in the 50s, those houses where pioneers of modernization, having telephone line, water supply and sewerage, which was not so common in mid-size Lithuanian towns before the war.

The designs of some progressive standardized single-family houses in Soviet Lithuania were influenced by Finish and possibly American architecture. Whilst, due to the prohibitions to build, they did not get a chance to be actually constructed on site. Nevertheless, their modernist, pavilion-type designs were applied to other typological groups.

The fact that the designs of most progressive standardized single-family houses were not realized, and the majority of the realized ones were of very poor architectural expression (walls of white silicate bricks, pitched roofs of slate), resulted in a non-existing tradition of middle-class family house. That partly was the cause of construction of post-modern architecture houses of enormous quantity of square meters in the 80 s and $90 \mathrm{~s}$, and might be one of the causes of today's eclectic single-family house architecture.

\section{REFERENCES}

1. Winston Churchill, 1874-1965, British Conservative statesman; Prime Minister, 1940-5, 1951-5 [online]. Oxford Reference [cited: 20. 09. 2016]. http:// www.oxfordreference.com/view/10.1093/acref/9780199572687.001.0001/ q-author-00002-00000334

2. Meuser, Ph., Zadorin, D. Towards a Typology of Soviet Mass Housing. Berlin: Dom Publishers, 2015, p. 12

3. Raginis, V., Sederevičius, V. 1960. LTSR rajoninių centrų sodybiniu gyvenamujų namų projektavimas ir statyba pokario metais. Lietuvos TSR architektūros klausimai I [Baršauskas, J., ed.]. Kaunas: Statybos ir ararchitektūros klausimai $I$ [Baršaus
chitektūros institutas, 1960 , p. 262.

4. Jakovlevas, K. Trobesių architektūrinių konstrukcijų pagrindai. Vilnius: Profleidykla, 1961, p. 10.

5. Kasperavičius, V. Stambiaplokštė statyba turi būti parodomoji. Statyba ir architektūra. No. 1/2, 1960, p. 3.

6. Bialopetravičius, V. Industrija - šiandieninès Lietuvos statybos pagrindas. Statyba ir architektūra. No. 7, 1961, p. 10. 
7. "Teisès aktų, reglamentavusių teritorijų planavimo, statybos ir valstybinès statybos kontrolès tvarką Lietuvoje 1947-1992 metais, sąrašas”. Vilnius 2009, pp. 17-18

8. Lietuvos KP CK ir Lietuvos TSR Ministru Tarybos nutarimas "Apie priemones gyvenamųjų namų statybai vystyti Lietuvos TSR”, in Tiesa, Vol. 25, 1958

9. Baršauskas, J., et al. Mažaaukščiai gyvenamieji namai iš surenkamųjų silikatiniu elementu. Statybos ir architektūros instituto straipsniu rinkinys. Kaunas: Statybos ir architektūros institutas, 1958, p. 228.

10. Colomina, B. Domesticity at War. Cambridge, MA: MIT Press, 2007, p. 55 .

11. Kumar, K. Modernization [online]. Britannica [cited: 01. 09. 2016]. https:// global.britannica.com/topic/modernization

12. Vieno aukšto 3 kambariu gyvenamojo namo projektas I-59-1. LTSR Ministru Tarybos Statybos ir architektūros reikalu komiteto leidinys. Vilnius, 1959 , p. 1.

13. Projektas $N r$. " $K-5$ ”. Kolūkiečio gyvenamasis namas. Vilnius: Valstybinè politinès ir mokslinès literatūros leidykla, 1951, p. 3

14. Saltenis, M. Nauji pastatai industrinei kaimo statybai. Statyba ir architektūra. No. 1, 1961, pp. 13-14.

15. Smith, E. Case Study Houses. Köln: Taschen, 2016, p. 6.

16. Žilye zdanija dlja individual'nogo stroitel'stva. Moskva: Gosstroj SSSR, 1969.

17. Ilgūnas, G. Lietuvos Respublikos I Vyriausybè, 1990-1991 m. Vilnius, 2008, p. 185.

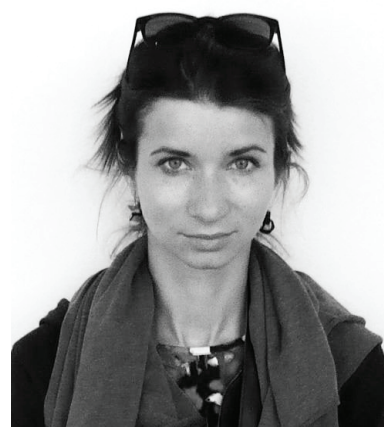

Aistė Galaunytè received the degree of Bachelor of architecture and Master of art history from Vilnius Gediminas Technical University in 2010 and 2013, respectively. She is currently a $\mathrm{PhD}$ student with VGTU and is working on her research thesis "Standardized architecture as a socio-political construct in Soviet Lithuania: the case of a single-family house" under the guidance of Dr. Tomas Grunskis. Since 2010, she has been a practicing architect. She is the author of articles in popular architectural press and an organizer of public architectural events.

\section{Contact Data}

\section{Aistė Galaunytė}

Vilnius Gediminas Technical University

Department of Architectural Fundamentals and Theory of Faculty of Architecture, VGTU

Address: 1 Trakų St., Vilnius, 01132, Lithuania

E-mail: aiste.galaunyte@vgtu.lt
18. 2011 Population and Housing Census [online]. Official Statistics Portal [cited: 25. 09. 2016]. http://osp.stat.gov.lt/en/temines-lenteles

19. Individuali liga. Statyba ir architektūra. No. 5, 1962, p. 33

20. Saltenis, M. Nauji pastatai kaimo industrinei statybai. Statyba ir architektūra. No. 1, 1961, p. 14

21. Colomina, B. Domesticity at War. Cambridge, MA: MIT Press, 2007, p. 93.

22. Dvieju aukštu 5 kambariu gyvenamojo namo projektas I-59-4. LTSR Ministru Tarybos Statybos ir architektūros reikalu komiteto leidinys. Vilnius, 1959

23. Archive of Institute of Architecture and Construction of Kaunas University of Technology.

24. Smith, E. Case Study Houses. Köln: Taschen, 2016, p. 34

25. Archive of Institute of Architecture and Construction of Kaunas University of Technology.

26. Barŝ, M., O. Arhitekturnoe proektirovanie žilyh zdanij. Moskva: Strojizdat 1964, p. 63.

27. Žilye zdanija dlja individual'nogo stroitel'stva. Moskva: Gosstroj SSSR, 1969 , p. 67. 